\title{
The effect of superphosphate and plant density on mini-tuber production from True Potato Seed (TPS)
}

\author{
Moses MUTETWA, Munashe SHOKO * and Tuarira MTAITA \\ Faculty of Agriculture and Natural Resources, Africa University, Box 1320, Old Mutare, Zimbabwe. \\ "Corresponding author, E-mail: shokom@africau.ac.zw, tamtaita@africau.ac.zw
}

\begin{abstract}
Improving tuber seed quality and availability is institutionally complex in the tropics and sub-tropics. This experiment was carried out at Africa University farm, Zimbabwe. The main objective of this work was to evaluate the effect of superphosphate and plant density on mini-tuber production from true potato seed. The enhancement of all growth variables was due to $\mathrm{P}$ availability in the soil allowing plants to develop without restrictions as rates increased. Days to maturity, shoot $\mathrm{P}$, tuber dry matter, shoot dry matter and specific gravity showed significant responses to superphosphate. This showed that phosphorus plays an important role in growth and development of the mini-tubers. Differences in the parameters measured as affected by increasing $\mathrm{P}$ rates were mainly between the lowest and the highest $\mathrm{P}$ treatments, suggesting that at lower rates of phosphate application, the nutrient was insufficient. Phosphorus showed significant yield increases with increase in application rates. Yield also increased significantly by weight with decreased planting spacings adopted.

() 2010 International Formulae Group. All rights reserved.
\end{abstract}

Keywords: Solanum tuberosum L, seedling tuber, phosphorus, nursery, yield.

\section{INTRODUCTION}

Poor potato (Solanum tuberosum L.) tuber seed quality is often cited as the most important factor limiting potato productivity in developing countries (Aldana, 2005). Moreover, formal certified seed tuber production is limited and faces technical, economical and managerial problems (Wooster and Hussain, 1995). Potato crop being vegetatively propagated is vulnerable to both pathological and physiological problems. This vegetative propagation is also constrained by the carry-over of pathogens and physiological degradation. One solution to potato seed problem could be the use of true potato seed (TPS) instead of conventional propagation from seed tubers (Schmiediche, 1997). True Potato Seed (TPS) is a captivating technology that offers farmers an option to overcome the expensive conventional, and weakness of clonally propagated tubers as a source of planting material (Chilver et al., 1997). Phosphorus is essential in many plant functions and is needed in a stable supply in order to avoid disruptions in plant growth. Application of $\mathrm{P}$ fertilizers is recommended to potato crops so as to increase the yield, quality and set of tubers (Jenkins and Ali, 2000; Marchner, 1995). Phosphate is also important at the initiation of tuber formation, a complex 
developmental process involving a number of important biological systems. Manipulation of seedling population in a seedbed is one method of producing a maximum number of usable seedling tubers. Planting density strongly affects yield, both by number and by weight, and more tubers and yield per square meter are expected in higher planting densities (Karafyllidis et al., 1997).

This work was carried out to determine the effect of planting densities and phosphorus application rates on production of mini-tubers from true potato seed.

\section{MATERIALS AND METHODS}

Description of the experimental site

The experiments were conducted at Africa University Farm (AU) in Mutare, Zimbabwe; located at $18^{\circ} 53^{`} \mathrm{~S}, 32^{\circ} 36^{`} \mathrm{E}$ and $1104 \mathrm{~m}$ asl. Average day length is 14 hours in summer to 11 hours in winter. Rainfall averages $800-1000 \mathrm{~mm}$ per year and temperature mean maximum are from $18{ }^{\circ} \mathrm{C}$ (July) to $32{ }^{\circ} \mathrm{C}$ (October). Hot summer is between September and December. The soil at AU farm is a red sandy clay loam, Fersiallitic 5E soil under Zimbabwe soil classification system (Nyamapfene, 1991).

\section{Experimental design and treatments applied}

A split-plot design with 4 phosphorus levels $[0,30,60 \& 90 \mathrm{~kg} \mathrm{P} / \mathrm{ha}]$ as the main plot factor and 3 planting density [15x30, 15x40 \& $20 \times 40 \mathrm{~cm}]$ as subplot factors was used. Each treatment was replicated three times. Seeds were planted in speedling trays and manually transplanted after five weeks from planting. Individual treatment plots were of a gross size $1.5 \mathrm{x} 2 \mathrm{~m}$. A Rainfall was supplemented by light irrigations. The entire phosphate fertilizer treatments were applied as basal fertilizer.

\section{Crop establishment and measurements}

Normal grower-practices were followed throughout the experimental period. This was done so as to maximize tuber yield and quality. Transplanting was done at 35 days after planting (DAP). A seedling survival count was recorded at 7 days after transplanting. Vines were cut 90 days after planting and tubers were harvested manually 10 days after removal of vines. Tubers were washed and weighed using digital scale, counted, and sorted into the following size categories: <30 mm; 30-55 mm and tuber >55 $\mathrm{mm}$ and cull tubers. Total yield included the combined weights of all categories.

\section{Variables measured}

The following parameters were measured following the protocol by AOAC (1990): shoot dry matter, days to maturity, number and weight of tubers, tuber sizes and weights, foliar P, specific gravity (SG), tuber phosphorus content, tuber dry matter, root dry matter and root length;

\section{Statistical analyses}

Statistical analysis of the data was performed using the STATISTICA software, version 8.02 program (StatSoft, 2004). Means were separated using Bonferroni studentised range for testing least significant differences at the 5\% level when ANOVA revealed significant $(\mathrm{P}<0.05)$ differences among the treatments.

\section{RESULTS}

Shoot dry matter

Significant $(\mathrm{P}<0.05)$ differences were recorded between SDM and $\mathrm{P}$ levels (Table 1). There was an increase in SDM with increase in $\mathrm{P}$ fertilization rates. Increases of $27.66 \%, 115.00 \%$ and $242.76 \%$ were noted for $30 \mathrm{~kg} \mathrm{P} \mathrm{ha}^{-1}, 60 \mathrm{~kg} \mathrm{P} \mathrm{ha}^{-1}$ and $90 \mathrm{~kg} \mathrm{P} \mathrm{ha}^{-1}$ treatments relative to the control. Significant $(\mathrm{P}<0.05)$ differences in above ground dry matter were also recorded as a result of varying plant density.

\section{Maturity and tuber quality}

Days to maturity increased with increase in the amount of phosphate applied (Table 1). The specific gravity for $30 \mathrm{~kg} \mathrm{P}$ $\mathrm{ha}^{-1}, 60 \mathrm{~kg} \mathrm{P} \mathrm{ha}{ }^{-1}$ and $90 \mathrm{~kg} \mathrm{P} \mathrm{ha}^{-1}$ treatments were significantly higher than the control. As the phosphorus application rate increased, the SG also increased significantly (Table 1). The 
significant $(\mathrm{P}<0.05)$ increase of specific gravity with a decrease in the plant density is because of the high dry matter content of the tubers produced with an increase in the plant spacing.

Tuber dry mater increased significantly with increase in $\mathrm{P}$ application (Table 1). Tuber dry matter increased with increased plant spacing (because at low density there are more nutrient elements for uptake by fewer plants than at higher densities resulting in more metabolic processes and more assimilates portioned to the tubers.

\section{Nutrient analysis}

The application of $\mathrm{P}$ significantly $(\mathrm{P}<0.05)$ increased shoots $\mathrm{P}$ content (Table 1). As the plant density increased, there was a significant decrease in $\mathrm{P}$ concentration in the shoot.

\section{Total tuber sizes and total tuber number}

As indicated in Table 2, the control produced more number of tubers (67.3 tubers $\mathrm{m}^{-2}$ ) than $30 \mathrm{~kg} \mathrm{P} \mathrm{ha}{ }^{-1}$ (48.6 tubers $\mathrm{m}^{-2}$ ) because of the higher average crop stand percentage for these plots.

The significant interaction of $\mathrm{P} \times \mathrm{D}$ on the number of tubers indicate the degree of influence of $\mathrm{P}$ and plant density (Table 3). At all $P$ levels, more tuber numbers of small size are produced with the highest plant density and decrease as the plant density decreases because at lower plant densities, there are less sinks.

\section{Tuber sizes and total yield $\left(\mathrm{t} \mathrm{ha}^{-1}\right)$}

There was a significant $\quad(\mathrm{P}<0.05)$ increase in the yield for the large sized tubers as the plant density decreased (Table 2).There was also a significant $(\mathrm{P}<0.05)$ level of interaction for PxD (Table 4). At any given level of the nutrient $\mathrm{P}$, there is a higher yield of the large sized tubers at lower plant density than at higher plant density because at high plant spacings tubers have more space during the bulking period.

Total tuber yield increased from low $\mathrm{P}$ fertilization to high $\mathrm{P}$ fertilization (Table 5). The highest yield increase of $47.74 \%$ was recorded at the highest nutrient level $(90 \mathrm{~kg} \mathrm{P}$ $\left.\mathrm{ha}^{-1}\right)$ relative to the control $\left(0 \mathrm{~kg} \mathrm{P} \mathrm{ha}{ }^{-1}\right)$.The lowest plant density produced the highest yield as shown in Table 5.

Table 1: Means of several agronomic characteristics and postharvest parameters as affected by plant spacing and $\mathrm{P}$ fertilizer rate.

\begin{tabular}{lcccccc}
\hline Treatment & $\begin{array}{c}\text { Maturity } \\
(\text { days })\end{array}$ & $\begin{array}{c}\text { Shoot P } \\
(\%)\end{array}$ & $\begin{array}{c}\text { TDMB } \\
(\%)\end{array}$ & $\begin{array}{c}\text { SDMB } \\
(\%)\end{array}$ & $\begin{array}{c}\text { Specific } \\
\text { gravity }\end{array}$ & $\begin{array}{c}\text { Tuber P } \\
(\%)\end{array}$ \\
\hline P Levels $^{(\boldsymbol{P})}$ & & & & & & \\
$P_{0 \mathrm{~kg} / \mathrm{Ha}}$ & $4.556 \mathrm{a}$ & $0.033 \mathrm{~d}$ & $25.290 \mathrm{c}$ & $19.270 \mathrm{~b}$ & $1.075 \mathrm{~d}$ & 0.026 \\
$P_{30 \mathrm{~kg} / \mathrm{Ha}}$ & $4.111 \mathrm{a}$ & $0.071 \mathrm{c}$ & $25.800 \mathrm{bc}$ & $24.600 \mathrm{~b}$ & $1.079 \mathrm{c}$ & 0.039 \\
$P_{60 \mathrm{~kg} / \mathrm{Ha}}$ & $3.333 \mathrm{~b}$ & $0.114 \mathrm{~b}$ & $27.310 \mathrm{~b}$ & $41.430 \mathrm{~b}$ & $1.084 \mathrm{~b}$ & 0.048 \\
$P_{90 \mathrm{~kg} / \mathrm{Ha}}$ & $2.556 \mathrm{c}$ & $0.136 \mathrm{a}$ & $29.690 \mathrm{a}$ & $66.050 \mathrm{a}$ & $1.089 \mathrm{a}$ & 0.043 \\
LSD $_{(0.05)}$ & 0.4576 & 0.015 & 1.832 & 1.712 & 0.001 & 0.001 \\
Density $^{(\boldsymbol{D})}$ & & & & & & \\
High & 3.750 & $0.083 \mathrm{z}$ & $26.320 \mathrm{z}$ & $33.010 \mathrm{z}$ & $1.079 \mathrm{z}$ & 0.040 \\
Medium $_{\text {Low }}$ & 3.417 & $0.089 \mathrm{yz}$ & $26.350 \mathrm{z}$ & $39.300 \mathrm{y}$ & $1.082 \mathrm{y}$ & 0.044 \\
LSD $_{(0.05)}$ & 3.750 & $0.094 \mathrm{y}$ & $28.400 \mathrm{y}$ & $41.200 \mathrm{y}$ & $1.083 \mathrm{y}$ & 0.032 \\
\hline
\end{tabular}


Table 2: Mean values of tuber yield as affected by plant spacing and fertilizer rate.

\begin{tabular}{|c|c|c|c|c|c|c|c|c|}
\hline \multirow{2}{*}{ Treatment } & \multicolumn{4}{|c|}{ Total number of tubers $\left(\mathrm{m}^{-2}\right)$} & \multicolumn{4}{|c|}{ Total Yield $\left(\mathrm{t} \mathrm{Ha}^{-1}\right)$} \\
\hline & $<30 \mathrm{~mm}$ & $30-55 \mathrm{~mm}$ & $>55 \mathrm{~mm}$ & Total & $<30 \mathrm{~mm}$ & 30-55mm & $>55 \mathrm{~mm}$ & Total \\
\hline \multicolumn{9}{|l|}{ P Levels ${ }^{(\mathbf{P})}$} \\
\hline$P_{0 k g / H a}$ & 10.5 & 42.3 & 14.5 & 67.3 & 2.75 & $3.3 b$ & 1.8 & $8.6 b$ \\
\hline$P_{30 \mathrm{~kg} / \mathrm{Ha}}$ & 10.4 & 27.7 & 10.5 & 48.6 & 2.50 & $3.5 b$ & 1.7 & $7.7 b$ \\
\hline$P_{60 \mathrm{~kg} / \mathrm{Ha}}$ & 10.5 & 42.3 & 32.2 & 85.0 & 3.26 & $4.1 b$ & 1.1 & $8.9 b$ \\
\hline$P_{90 \mathrm{~kg} / \mathrm{Ha}}$ & 10.2 & 45.8 & 18.1 & 74.1 & 3.42 & $6.4 \mathrm{a}$ & 2.7 & $12.8 \mathrm{a}$ \\
\hline \multicolumn{9}{|l|}{ Density ${ }^{(D)}$} \\
\hline High & $15.5 x$ & 37.2 & 23.3 & 76.0 & 3.06 & 4.05 & $0.9 \mathrm{z}$ & $8.7 \mathrm{z}$ \\
\hline Medium & $8.7 y$ & 35.3 & 18.9 & 62.9 & 2.79 & 3.64 & $1.6 z$ & $8.9 \mathrm{z}$ \\
\hline Low & $7.0 \mathrm{z}$ & 46.1 & 14.2 & 67.3 & 3.11 & 5.21 & $3.0 \mathrm{y}$ & $10.9 y$ \\
\hline Mean & 10.4 & 39.5 & 18.8 & 68.7 & 2.98 & 4.30 & 1.8 & 9.5 \\
\hline $\operatorname{LSD}_{(0.05)}$ & 0.2 & NS & NS & NS & NS & NS & 0.7 & 1.4 \\
\hline
\end{tabular}

Table 3: Means for interaction of Phosphate fertilization and Plant Density on tuber number production.

\begin{tabular}{|c|c|c|c|c|}
\hline Treatment & & & & \\
\hline & $P_{0 \mathrm{~kg} / \mathrm{Ha}}$ & $P_{30 \mathrm{~kg} / \mathrm{Ha}}$ & $P_{60 \mathrm{~kg} / \mathrm{Ha}}$ & $P_{90 k g / H a}$ \\
\hline High & $15.809 a$ & $15.294 b$ & $15.729 a$ & $15.077 b$ \\
\hline Medium & $8.816 \mathrm{c}$ & $8.637 \mathrm{c}$ & $8.694 \mathrm{c}$ & $8.663 c$ \\
\hline $\begin{array}{l}\text { Low } \\
\operatorname{LSD}_{(0.05)}\end{array}$ & $\begin{array}{l}6.990 \mathrm{~d} \\
0.3318\end{array}$ & $7.124 d$ & $6.972 d$ & $6.968 \mathrm{~d}$ \\
\hline
\end{tabular}

Table 4: Means for interaction of phosphate fertilization and plant density on large size tuber yield.

\begin{tabular}{|c|c|c|c|c|}
\hline Treatment & \multicolumn{4}{|c|}{ P Levels ${ }^{(P)}$} \\
\hline \multirow{2}{*}{$\begin{array}{l}\text { Density }^{(\boldsymbol{D})} \\
\text { High }\end{array}$} & $P_{0 \mathrm{~kg} / \mathrm{Ha}}$ & $P_{30 \mathrm{~kg} / \mathrm{Ha}}$ & $P_{60 \mathrm{~kg} / \mathrm{Ha}}$ & $P_{90 \mathrm{~kg} / \mathrm{Ha}}$ \\
\hline & $0.36 \mathrm{c}$ & $1.21 \mathrm{bc}$ & $0.28 \mathrm{c}$ & $1.68 \mathrm{bc}$ \\
\hline Medium & $0.84 b c$ & $1.67 \mathrm{bc}$ & $1.73 b c$ & $2.26 \mathrm{~b}$ \\
\hline Low & $4.27 \mathrm{a}$ & $2.20 \mathrm{~b}$ & $1.36 \mathrm{bc}$ & $4.01 \mathrm{a}$ \\
\hline $\operatorname{LSD}_{(0.05)}$ & 1.519 & & & \\
\hline
\end{tabular}

Table 5: Means for interaction of phosphate fertilization and plant density on total yield.

\begin{tabular}{|c|c|c|c|c|}
\hline Treatment & \multicolumn{4}{|c|}{ P Levels ${ }^{(P)}$} \\
\hline \multirow{2}{*}{$\begin{array}{l}\text { Density }^{(\boldsymbol{D})} \\
\text { High }\end{array}$} & $P_{\text {Okg/Ha }}$ & $P_{30 k g / H a}$ & $P_{60 \mathrm{~kg} / \mathrm{Ha}}$ & $P_{90 \mathrm{~kg} / \mathrm{Ha}}$ \\
\hline & $5.82 \mathrm{e}$ & $7.03 \mathrm{de}$ & $9.86 \mathrm{bcd}$ & $12.05 \mathrm{ab}$ \\
\hline Medium & $7.22 \mathrm{de}$ & $7.09 \mathrm{de}$ & $9.39 \mathrm{bcd}$ & $11.71 \mathrm{abc}$ \\
\hline Low & $12.86 \mathrm{a}$ & $8.96 \mathrm{~cd}$ & $7.45 \mathrm{de}$ & $14.48 \mathrm{a}$ \\
\hline $\operatorname{LSD}_{(0.05)}$ & 2.925 & & & \\
\hline
\end{tabular}




\section{DISCUSSION}

Shoot dry matter

Low plant density facilitated more interception of the photosynthetic active radiation, which might have led to production of more above ground biomass. Also higher $\mathrm{P}$ levels provided the element for structural development and vegetative growth of the plants hence a higher performance in plant height, leaf numbers and shoot dry matter than at lower P levels.

\section{Maturity and tuber quality}

Senescence of the foliage at low P level was triggered earlier possibly by a deficiency in a mobile element $\mathrm{P}$ in the plant compared to plants grown at higher $\mathrm{P}$ level. The significant increase of specific gravity with a decrease in the plant density may be attributed to high dry matter content of the tubers produced under wider plant spacing. The extended growth period with increase in the phosphate meant more assimilates to the sinks resulting in increased dry matter production. Specific gravity is affected directly by the amount of dry matter accumulated in the tubers.

The research finding by Marchner (1995) that an increase in P generally leads to increased rate of most metabolic processes including photosynthesis is consistent with the findings of this research. An increase in TDM due to wider spacings may be attributed to reduced competition for nutrients by plants. These results are in line with work done by Fonseka et al. (1996) and Veeranna et al. (1997).

\section{Total tuber sizes and total tuber number} $\mathbf{m}^{-2}$

The decrease in total number of tubers due to a decrease in low density planting produced fewer sinks per unit area and increased as the planting density increased. This result is consistent with those of Patel et al. (2002) and Karafyllidis et al. (1997).

\section{Tuber sizes and total yield $\left(\mathrm{t} \mathrm{ha}^{-1}\right)$}

At a lower plant density, the competition for the nutrient element will be reduced hence more tuber yield. (Georgakis et al., 1997) and Deka et al. (1996) also concluded that the tuber yield was highest with the widest spacing studied. However, Saikia and Rajkhowa (1998) reported that the row spacing of $50 \times 10 \mathrm{~cm}$ produced higher marketable tuber yield than the wider spacing (12.0 vs. 10.6 t/ha respectively). High $\mathrm{P}$ rates resulted in higher yields. This has been supported by Maier et al. (1989) and Rosen and McNearney (2003) who also found out that phosphate application resulted in significantly greater tuber yields because the phosphate supplies a high nutrient base for growth and development of the plant.

\section{Conclusion}

Results of this study have shown that, the use of low plant density can significantly increase yield per unit area. Planting density strongly effect yield by weight than by numbers. It can also be concluded that by increasing the planting density, the percentages of the small size tubers produced are increased. In potato seed production, high tuber number per plant is desired. Applying zinc apparently alleviated the negative effect of excess phosphorus, although only at the high rates of phosphorus. Hence, the significant differences observed within and between treatments for root length, root dry matter, $\mathrm{P}$ uptake and specific gravity produced by the TPS imply that fertilization has a positive effect in potato mini-tuber production from TPS. Foliar P concentration increases with increased $\mathrm{P}$ fertilization and at lower $\mathrm{P}$ application rates shoot $\mathrm{P}$ concentration can be increased by zinc fertilization. Based on these findings, $\mathrm{P}$ nutrition appears to play a role in regulating tuber set, but the effect of $\mathrm{P}$ may be inconsistent due to interactions with the multiple factors affecting tuber initiation.

\section{ACKNOWLEDGEMENTS}

The authors would like to extend many thanks to the Regional Universities Forum for Capacity Building in Agriculture [RUFORUM] for fully funding this research. 


\section{REFERENCES}

Aldana ME. 2005. Effect of phosphorus and potassium fertility on fruit quality and growth of tabasco pepper (Capsicum frutescens) in hydroponic culture. M.Sc Thesis, Graduate faculty of the Louisiana State University and Agricultural and Mechanical College.

AOAC (Association of Official Analytical Chemists). 1990. Official Methods of Analysis $\left(15^{\text {th }}\right.$ edn). AOAC Inc.: Arlington, Virginia, USA.

Chilver R, El-Bedewy, Rizk A. 1997. True Potato Seed: Research, Diffusion and Outcomes in Egypt. CIP: Lima, Peru; 128.

Deka NC, Ullah Z, Dutta TC. 1996. Effect of TPS genotypes and spacing on potato production. J. Agri. Sci. Society of North East India, 9: 207-208.

Fonseka HD, Asanuma K, Kusutani A, Ghosh AK, Ueda K. 1996. Growth and yield of potato cultivars in spring cropping. I. Plant morphology, growth, assimilates partitioning and yield under two planting densities. Japanese J. Crop Sci., 65(2): 269-276.

Jenkins PD, Ali H. 2000. Phosphate supply and progeny tuber numbers in potato crops. Ann. Appl. Biol., 136:41-46.

Karafyllidis DI, Georgakis DN, Stavropoulos NI, Nianiou EX, Vezyroglou IA. 1997. Effect of planting density and size of potato seed-minitubers on their yielding capacity. Acta Hort. (ISHS), 462: 943950.

Maier NA, Potocky-Pacay KA, Williams CMJ. 1989. Effect of phosphorus fertiliser on the yield of potato tubers (Solanum tuberosum L.) and the prediction of tuber yield response by soil analysis. Australian Journal of Experimental Agriculture.

Marchner H. 1995. Mineral Nutrition of Higher Plants (2nd edn). Academic Press Inc: Sand Diego.

Nyamapfene K. 1991. The Soils of Zimbabwe. Nehanda Publishers: Zimbabwe.

Patel BT, Barad AV, Chaudhari SM, Patel CK, Patel RN. 2002. Standardization of spacing for seed tuberlet production from TPS under nursery beds in Gujrat. $J$. Indian Potato Assoc., 29(3-4): 143-146.

Saikia M, Rajkhowa DJ. 1998. Effect of planting density and vermicompost on yield of potto raised from seedling tubers. J. Indian Potato Assoc., 25(3-4): 141142.

Schmiediche P. 1997. Overview of CIP work in East and Southeast Asia and the Pacific. International Potato Center program report 19995-1996. pp. 15-18.

Statsoft, 2004. STATISTICA (data analyses software systems) version 7, StatSoft. Inc Tulsa, Oklahoma, USA.

Veeranna HK, Abdul Khalak, Khalak A. 1997. Effect of spacing and fertilizer levels on growth parameters and dry matter production of potato crop raised from TPS seedlings. Crop Res. Hisar., 14(1): 119-126.

Wooster P, Hussain A. 1995. National Potato Seed Strategy Document. Pak Swiss Potato Development Project, PARC, Islamabad, Pakistan, 20 p. 